\title{
Study on the construction of underground reservoirs on Zhoushan Island and related environmental issues based on the use of typhoon rain
}

\author{
Zhou Ye , Danna Zhou, and Fang Chen \\ Zhejiang Ocean University, School of Marine Engineering Equipments, Zhoushan 316004, Zhejiang, \\ China
}

\begin{abstract}
Water resources in the island area vary greatly from year to year and are unevenly distributed within the year, especially during typhoon and rainstorm periods when the lack of reservoirs leads to a large loss of rainfall and flood resources. In order to improve the water resources supply capacity of the island, this paper takes the excavated underground reservoir on Zhoushan Island as the research object to solve the problem of abundant rainfall and flood resources but lack of saving space during the plum and typhoon floods, and to enhance the self-sufficiency of water resources on the island. The study focuses on three environmental issues in the construction of underground reservoirs, and analyses the actual effect of the resourceful use of rainwater floods using the actual measurement data of Typhoon 2106 ( In fa) to prove the feasibility of the construction of underground reservoirs. It makes a useful exploration for the future planning and construction of underground reservoirs on Zhoushan Island using underground space resources to solve water shortage.
\end{abstract}

\section{Introduction}

Many studies have been done by domestic scholars in the past. You Chunfeng[1] and others transformed the reservoir into a "combined surface-underground" reservoir through vertical impermeability treatment of the dam base, which improved the storage capacity and water supply assurance of the reservoir; Li Tong[2] aimed at maximising the utilization of water resources and minimising water abandonment after combined surface water and groundwater regulation, and established Yang Yun et al.[3] used operational research methods to establish an optimal dispatching model for the joint use of multiple reservoirs for water supply, simulating the joint use of plain reservoirs and underground reservoirs; Wang Xingchao[4] demonstrated the feasibility of underground reservoirs in sponge city construction through basic issues such as storage, purification and water circulation paths; Wang Congrong et al.[5] considered that pit-type underground reservoirs would be an important development direction in this field, and proposed that the water quality and quantity of the rechargeable water source should be considered comprehensively. This

* Corresponding author : 3043109291@qq.com 
paper takes Zhoushan Island as an example to study open underground reservoirs and related environmental issues, and to explore the technology of resource utilisation of rain and wind on the island platform.

\section{Zhoushan Island water system and underground reservoir scheme}

\subsection{Overview of the Zhoushan Island water system}

The city's average annual precipitation is $1275.2 \mathrm{~mm}$, and the city's average maximum annual rainfall is $1648.5 \mathrm{~mm}$ (1967). Zhoushan Island has no large water system, and the rivers on the island do not affect each other and flow into the sea alone. The upper reaches of the river basins are mountainous rivers, with high and low floods; the lower reaches enter the plains, where the river slopes gently and are influenced by the tides, with the characteristics of coastal plain rivers. The topographic map of the Zhoushan Island water system is shown in Figure 1.

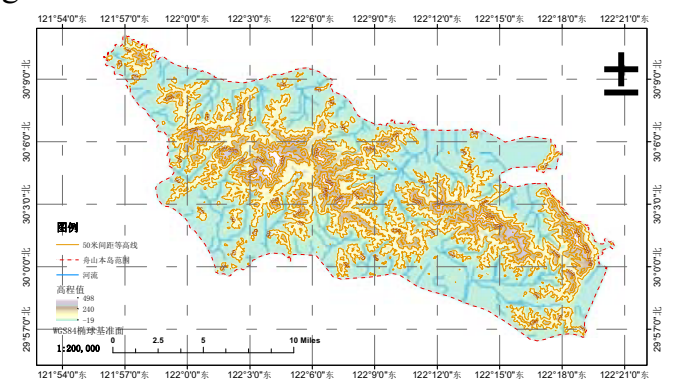

Fig. 1. Topographic map of Zhoushan Island water system

\subsection{Causes of water shortage on Zhoushan Island}

\subsubsection{Difficulties in storing water in short and fast flowing rivers}

The topographical conditions make it difficult to store water in the short flow of the source, and most of the rivers have already been "built as reservoirs and ponds", with limited potential for subsequent conventional surface water development. The total storage capacity of the island's reservoirs, ponds and rivers is about 110 million $\mathrm{m}^{3} .370 .00 \mathrm{~km}^{2}$ of rainwater is collected in the mountains, and $150.00 \mathrm{~km}^{2}$ of rainwater is collected in the reservoirs and ponds, with a utilization rate of more than $30 \%$.

\subsubsection{Uneven spatial and temporal distribution of rainfall}

Although the average annual rainfall of Zhoushan Island is $1399.50 \mathrm{~mm}[6]$ and the evaporation of land surface is $758.30 \mathrm{~mm}$, the total water resources are 300 million $\mathrm{m} 3$ [7] , there is also an uneven distribution of rainfall between and within years. 1980-2020 annual precipitation ranges from 872 to $2108 \mathrm{~mm}$, with an extreme ratio of 2.4 times. During the typhoon period from July to October, precipitation accounts for $35-45 \%$ of the annual precipitation. The monthly precipitation for 2018 and 2019 at Dinghai Station on Zhoushan Island is shown in Figure 2. 


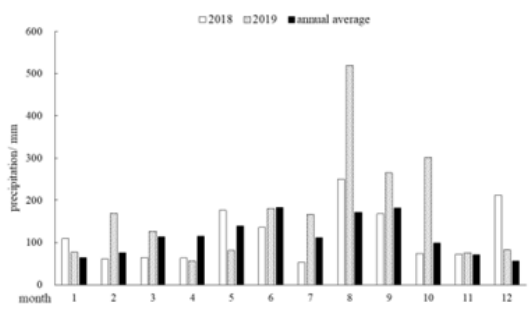

Fig. 2. Monthly precipitation at Dinghai Station, Zhoushan Island

\subsubsection{Substandard water quality in mainland diversions}

The first phase of the mainland water diversion project has a water supply scale of $1 \mathrm{~m}^{3} / \mathrm{s}$ $\left(86,000 \mathrm{~m}^{3} / \mathrm{d}\right)$, with a total annual average diversion volume of 21.6 million $\mathrm{m} 3$. The second phase of the mainland water diversion project has a design diversion flow of $2.80 \mathrm{~m}^{3} / \mathrm{s}$, with an average annual diversion volume of 66.33 million $\mathrm{m} 3$. The third phase of the Zhoushan mainland water diversion project has a design diversion flow of $1.20 \mathrm{~m}^{3} / \mathrm{s}$, with an average diversion volume of 32 million $\mathrm{m}^{3}$. However, there are many uncertainties such as interruptions due to damaged or burst water pipes; at the same time, the water quality is heavily polluted, with iron and manganese levels in the water bodies exceeding the Environmental Quality Standard for Surface Water (GB3838-2002).

\subsubsection{Desalination is not yet widespread}

According to China.org Ocean China 2019, Zhoushan has built 17 desalination plants and 26 desalination projects, with a desalination capacity of 137,000 tons per day. However, there are also problems such as high cost of water production, poor stability of water quality and low awareness of public acceptance.

\subsection{Use of typhoon rain}

\subsubsection{Typhoon trends}

Among the 46 typhoons that have landed in Zhejiang since the founding of the People's Republic, the number of typhoons that have landed in Zhejiang since 1978 is 33, i.e. 2.5 times that of the first 30 years in the last 40 years. 21 typhoons have landed between 2000 and 2021. Since the founding of the People's Republic of China, there have been 10 strong typhoons of magnitude 14 or above, 2 before 2000 and 8 after $2000.75 \%$ of the typhoons that have landed in Zhoushan since 2000 have done so. Table 1 shows the impact of typhoons landing in Zhejiang on the rainfall at Dinghai Station on Zhoushan Island.

Table 1. Impact of typhoons registered in Zhejiang on rainfall at Dinghai Station, Zhoushan Island since 2000

\begin{tabular}{c|c|c|c|c}
\hline Typhoon Landfall Range & $\begin{array}{c}\text { Number of } \\
\text { typhoons }\end{array}$ & $\begin{array}{c}100 \mathrm{~mm} \text { or } \\
\text { more }\end{array}$ & $\mathbf{5 0 - 1 0 0 \mathrm { mm }}$ & Under 50mm \\
\hline $\begin{array}{c}\text { Zhejiang-Fujian Province border - } \\
\text { Pingyang County }\end{array}$ & 5 & $\mathbf{2 0} \%$ & $\mathbf{2 0 \%}$ & $\mathbf{6 0} \%$ \\
\hline Wenzhou City - Wenling City & $\mathbf{8}$ & $\mathbf{5 0 \%}$ & $\mathbf{3 7 . 5 \%}$ & $\mathbf{1 2 . 5 \%}$ \\
\hline Jiaojiang City - Xiangshan County & 4 & $\mathbf{7 5 \%}$ & $\mathbf{0 \%}$ & $\mathbf{2 5 \%}$ \\
\hline Zhoushan Island and Hangzhou Bay & 4 & $\mathbf{7 5 \%}$ & $\mathbf{0}$ & $\mathbf{2 5 \%}$ \\
\hline
\end{tabular}




\subsubsection{Typhoon stormwater resourcefulness possibilities}

There are 77 reservoirs on Zhoushan Island, with a normal storage capacity of 78.528 million $\mathrm{m}^{3}$, a dead storage capacity of $950,000 \mathrm{~m}^{3}$, a rainfall catchment area of $113.4 \mathrm{~km}^{2}$, a water diversion area of $10.73 \mathrm{~km}^{2}$, a multi-year average runoff of 74.484 million $\mathrm{m}^{3}$ and an average storage capacity coefficient of 1.0415 , but there is also an uneven inter- and intra-annual rainfall distribution. The storage capacity coefficient of Zhoushan Island reservoirs is significantly higher than that of mainland reservoirs, so the potential for dispatching is not great from this point of view, but from the changes in typhoons over the past 20 years, there is still great potential. However, judging from the trend of typhoon changes over the past 20 years, there is still a huge potential.

\subsubsection{Underground Reservoir Programme}

The special planning for water supply in Zhoushan City predicts that the per capita water consumption target for Zhoushan City in 2030 will be $450 \mathrm{~L}$ /day-per person, and the total water supply for Zhoushan Island in 2030 will be 82.125 million $\mathrm{m}^{3} .30$ million $\mathrm{m}^{3}$ of underground reservoir capacity is proposed, and the total capacity of surface and underground reservoirs will be 60 million $\mathrm{m}^{3}$, which will ensure water for production and living at a $90 \%$ guarantee rate. The water quality and cost of the reservoirs will be used as indicators, and the storage level of the underground reservoirs must not be lower than the average tide level for many years to prevent seawater from backing up and causing pollution to the water quality.

\section{Environmental issues related to groundwater reservoirs}

\subsection{Ecological protection issues in the watershed}

Due to the shortage of water resources, the reservoir capacity factor (reservoir capacity/total annual runoff) of the reservoirs built in Zhoushan has reached 1.2 on average, while that of other cities and counties in Zhejiang is roughly 0.3 . Building underground reservoirs will further expand the reservoir capacity factor and aggravate ecological damage, and the ecosystem is weak, there is an urgent need to strengthen the ecological management of the compound basin. In the "Zhejiang Province Water Resources Department on strengthening the construction of beautiful rivers and lakes" and "Zhejiang Province Water Ecological Environmental Protection "14th Five-Year Plan" are proposed to put water ecological protection in an important position. Therefore, the reservoir area should be greened and the side slopes and ditches should be treated to control soil erosion. The original ecological environment downstream of the watershed should be considered to ensure the flow of ecological environment in each watershed after the completion of the reservoir and dynamically monitor the interaction effect between the underground reservoir and ecological.

\subsection{Geological lithology issues}

The distribution and development of the Quaternary sediments in the survey area are mainly controlled by geomorphology and sea level rise and fall, with complex genetic types, mainly Upper Pleistocene alluvial lacustrine (al-1Q3) clay, silty clay with silty clay and muddy sand and gravel, etc.; Holocene marine sedimentary (mQ4) silty clay, with residual slope deposits (el-dlQ4) accumulating on the slopes and along the foot of the slopes. The bedrock type of Zhoushan Island basically belongs to impermeable tuffs and fused tuffs, 
and the mountain is strong, with engineering geological conditions for the construction of underground reservoirs.

\subsection{Groundwater reservoir water quality assurance issues}

In terms of water quality testing, a study was carried out on the changes in water quality in the underground pit water storage in Dingjiashan, Mamu, Zhoushan City [8]. The results show that: the overall situation of water quality is good, but there are also problems such as the low number of indicators tested; limited space for experiments on water storage in the pit; and inconsistent water quality testing standards and methods. The test results are shown in Table 2.

Table 2. Test items in the Mamu Dingjia cave bank

\begin{tabular}{c|c|c|c|c|c|c}
\hline Test unit & \multicolumn{2}{|c|}{ Unit 1 } & \multicolumn{2}{c|}{ Unit 2 } & \multicolumn{2}{c}{ Unit 3 } \\
\hline Test time & $\begin{array}{c}17.4-12 \\
(28 \text { times })\end{array}$ & $\begin{array}{c}18.1-7 \\
(5 \\
\text { times })\end{array}$ & $\begin{array}{c}18.4-19.1 \\
(5 \text { times })\end{array}$ & $\begin{array}{c}19.4-9 \\
(5 \text { times })\end{array}$ & $\begin{array}{c}19.3-8 \\
(2 \text { times })\end{array}$ & $\begin{array}{c}19.4-9 \\
(5 \text { times })\end{array}$ \\
\hline $\begin{array}{c}\text { Test } \\
\text { indicators }\end{array}$ & $\begin{array}{c}\text { PH, ammonia } \\
\text { nitrogen, } \\
\text { permanganate } \\
\text { index and 8 } \\
\text { other indicators }\end{array}$ & $\begin{array}{c}\text { Same } \\
\text { as left }\end{array}$ & $\begin{array}{c}\text { PH, ammonia } \\
\text { nitrogen, } \\
\text { permanganate } \\
\text { index and 7 } \\
\text { other indicators }\end{array}$ & $\begin{array}{c}\text { PH } \\
\text { temperature, } \\
\text { turbidity, } \\
\text { dissolved } \\
\text { oxygen }\end{array}$ & $\begin{array}{c}\text { (GB5749-2006) } \\
\text { Tables 1 and 2, } \\
\text { (GB3838-2002) } \\
\text { Tables 1 and 2 } \\
\text { of 49 indicators }\end{array}$ & $\begin{array}{c}\text { permanganate } \\
\text { index and 9 } \\
\text { other } \\
\text { indicators }\end{array}$ \\
\hline
\end{tabular}

Thus, the following attempts can be made to safeguard water quality: i. routine 29 tests are carried out daily and 109 indicators are tested twice a year; ii. attention is paid to algae-derived odour substances such as 2-methylisobornyl (2-MIB), geosmin (GSM), $\beta$-violetone ( $\beta$-Ion), $\beta$-cyclic citral ( $\beta$-cyc), dimethyl trisulphide (DMTS), 2-isopropyl-3 methoxypyrazine (IPMP) and 2-isobutyl-3-methoxypyrazine (IBMP) and 2,4,6-trichloroanisole (TCA), which has an earthy smell; iii. Carry out regular dispatching to enable dynamic water flow in the reservoir and increase the amount of dissolved oxygen in the water.

\section{Calculation of flood control dispatch during Typhoon 2106 (In fa)}

\subsection{Basic information on Typhoon 2106 (In-fa)}

Typhoon No. 6 of 2021 "In fa" made landfall in Putuo District, Zhoushan at 12:30 on July 25 , with a central pressure of $965 \mathrm{hPa}$ and a maximum wind force of 13 near the centre (typhoon level), the fifth typhoon to make direct landfall in Zhoushan since 1949.From 8:00 p.m. on July 24 to 10:00 p.m. on July 28, 2021, the rainfall at the main 7 reservoir stations on Zhoushan Island was above $480 \mathrm{~mm}$, with a range of $481-536 \mathrm{~mm}$; the maximum hourly rainfall was $37 \mathrm{~mm}$, with a range of $23.5-37 \mathrm{~mm}$, and the maximum rainfall was at 1:00 p.m. on July 25, lasting for 1 hour. Rainfall duration was between 72-81 hours. 94 hours of rainfall of no more than $6 \mathrm{~mm}$ fell between 10.00 hours on 28 July and 8.00 hours on 1 August. 


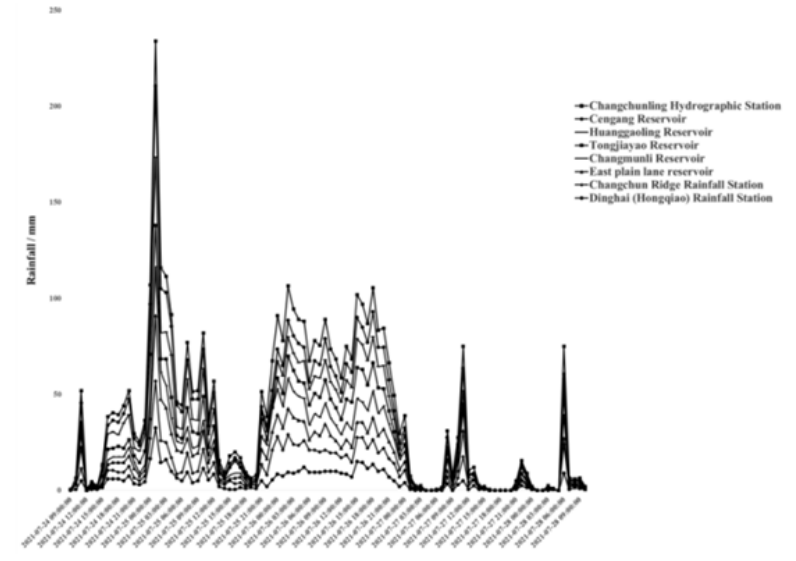

Fig. 3. Rainfall statistics at 8 measuring stations on Zhoushan Island during the typhoon 2106 (In fa)

\subsection{Flood resource balance analysis during typhoons}

In the calculation of the water balance of the operating reservoirs on this island, 77 reservoirs are calculated according to normal operation, the storage rate of the reservoirs that fail to operate normally is calculated according to the average storage rate of normal operation for each node, and the runoff coefficient is calculated according to 0.8, i.e. $400,000 \mathrm{~m}^{3}$ of runoff volume is formed per square kilometre. After analysis, it can be obtained that the normal storage capacity of 77 operating reservoirs on the island during the typhoon is $79,483,000 \mathrm{~m}^{3}$, the total area of rain collection is $123.69 \mathrm{~km}^{2}$, the formation of surface runoff is $49,476,000 \mathrm{~m}^{3}$, the increase of water storage is $17,235,000 \mathrm{~m}^{3}$, the pre-discharge is $1,526,000 \mathrm{~m}^{3}$, the interception of water storage during the typhoon is $30,485,000 \mathrm{~m}^{3}$, the total water discharge is $33,608,000 \mathrm{~m}^{3}$.

Table 3. Summary of the water balance of the 77 operating reservoirs on the island

\begin{tabular}{cccccccccc}
\hline Region & $\begin{array}{c}\text { Num } \\
\text { ber } \\
\text { of } \\
\text { seats }\end{array}$ & $\begin{array}{c}\text { Normal } \\
\text { storage } \\
\text { capacity }\end{array}$ & $\begin{array}{c}\text { Rainwater } \\
\text { catchment } \\
\text { area }\end{array}$ & $\begin{array}{c}\text { Total } \\
\text { runoff }\end{array}$ & $\begin{array}{c}\text { Previous } \\
\text { storage } \\
\text { capacity }\end{array}$ & $\begin{array}{c}\text { Intermediate } \\
\text { storage } \\
\text { capacity }\end{array}$ & $\begin{array}{c}\text { Later } \\
\text { storage } \\
\text { capacity }\end{array}$ & $\begin{array}{c}\text { Impact } \\
\text { overflow }\end{array}$ & $\begin{array}{c}\text { Total } \\
\text { discharg } \\
\text { e flow }\end{array}$ \\
\hline $\begin{array}{c}\text { Dinghai } \\
\text { District }\end{array}$ & 52 & 3070.5 & 65.67 & 2626.8 & 1384.2 & 2899.7 & 2217 & 1111.3 \\
$\begin{array}{c}\text { Water } \\
\text { Company }\end{array}$ & 7 & 3225 & 32.28 & 1291.2 & 2001 & 2922 & 2532 & 355.2 & 808.2 \\
$\begin{array}{c}\text { Putuo District } \\
\text { XinCheng }\end{array}$ & 7 & 610.3 & 8.42 & 336.8 & 195.1 & 351.9 & 349.7 & 276.4 & 282.2 \\
$\begin{array}{c}\text { District } \\
\text { Total }\end{array}$ & 71 & 1042.5 & 17.32 & 692.8 & 591.3 & 1042.5 & 815.02 & 241.6 \\
\hline
\end{tabular}

\subsection{Results of reservoir scheduling calculations during typhoons}

Water resources dispatch calculation using the influence of typhoon 2106: 77 surface reservoirs and 30 million $\mathrm{m}^{3}$ of underground reservoirs on the island participate in the dispatch, and 49.476 million $\mathrm{m}^{3}$ of surface runoff is formed in the reservoir area, and the joint dispatch of surface and underground reservoirs can increase the water resources of underground reservoirs by 33.608 million $\mathrm{m}^{3}$. From the previous analysis, it can be seen that the average multi-year water resources distribution on Zhoushan Island is bimodal, i.e. $35-40 \%$ in the plum rainy season and about $35-45 \%$ in the typhoon rains. The rainfall of $513.5 \mathrm{~mm}$ from the typhoon(In fa) is about $36.6 \%$ of the multi-year average rainfall of 
$1399.5 \mathrm{~mm}$, and a comprehensive consideration shows that the capacity of the chosen underground reservoir is suitable.

\section{Conclusion}

This paper studies the technical problems related to the construction of underground reservoirs on islands, and concludes that the excavation of underground reservoirs in island areas can make efficient use of rainwater resources, especially for the resourceful use of typhoon rain, and can effectively solve the shortage of water resources on islands. However, the construction of underground reservoirs will bring about many environmental problems. To ensure the safety of underground reservoirs and their water use, the study discusses four aspects, including typhoon change trends, ecological protection of composite watersheds, geological lithology and structure of the reservoir area and water quality assurance. This lays the foundation for subsequent research on the topic of underground reservoirs on Zhoushan Island. The specific site selection and rainfall resource scheduling mode of the underground reservoir on Zhoushan Island can be further analyzed, and the key technologies for the construction of the underground reservoir can be explored.

\section{Acknowledgements}

National Natural Science Foundation of China (51979249)

\section{References}

1. C. You, H. Zhang, The idea of converting Suihua Hongxing Reservoir into a "combined surface-underground reservoir", Heilongjiang Science and Technology of Water Consercancy, 42(07), 238-240(2014)

2. T. Li, Joint regulation of surface water and groundwater considering flood resources, Dalian University of Technology, (2020)

3. Y. Yang, W. Wang, The joint use of plain reservoir and underground reservoir in Ganyu County, Jiangsu Province, China Rural Water and Hydropower, 01, 26-30(2016)

4. X. Wang, Application of underground water reservoirs in construction of sponge cities, Advances in Science and Technology of Water Resources, 38(01), 83-87(2018)

5. C. Wang, A. You, L. Shu, Current situation and prospect on groundwater reservoir research, Zhejiang Hydrotechnics, 46(05), 68-71(2018)

6. T. Ho, H. Gong, An analysis of precipitation variation patterns in the past 64 years in the eastern Zhejiang islands - an example of Zhoushan Island,Zhejiang Hydrotechnics, 48(03), 20-21+33(2020)

7. X. Geng, Y. Jin, Research on building a security system of water resources in Zhoushan archipelago new are, Journal of Zhejiang Ocean University(Humanities science), 32(01), 18-23(2015)

8. Y. Weng, J. Ke, M. Xu, Feasibility analysis of the construction of an underground reservoir on Zhoushan Island, Zhejiang Hydrotechnics, 47(06), 77-80(2019) 